\title{
PALYNOLOGY OF THE AGUARDIENTE AND LOWER CAPACHO - FORMATIONS, CATATUMBO BASIN, COLOMBIA
}

\author{
PALINOLOGÍA DE LA PARTE BAJA DE LA FORMACIÓN CAPACHO - \\ FORMACIÓN AGUARDIENTE, CUENCA DEL CATATUMBO, COLOMBIA \\ PALINOLOGIA DA PARTE BAIXA DA FORMAÇÃO CAPACHO - FORMAÇÃO \\ AGUARDIENTE, BACIA DO CATATUMBO, COLÔMBIA
}

Guillermo Rodríguez-Forero ${ }^{1 *}$, Felipe de la Parra-Bonilla ${ }^{1}$, María-Carolina Vargas Fúquene $^{1}$ and Omar-Giovanni Bedoya-Martínez'.

'Ecopetrol S.A - Instituto Colombiano del Petróleo, Km 7 vía Piedecuesta, Santander, Colombia.

e-mail: guillermo.rodriguezf@ecopetrol.com.co

(Received: Dec. 30, 2014; Accepted: Ago. 23, 2017)

\begin{abstract}
T

he Catatumbo Basin is located in the North East of Colombia and is the opposite side of the Maracaibo basin in Venezuela. Although the main hydrocarbon reservoirs belong to the Cenozoic, the Cretaceous also has reported good results in oil production. The Aguardiente Formation is one of the main Cretaceous reservoirs of the basin. Key aspects of this Formation including age and depositional environment are still unclear. In this paper, we analyze the palynology of 86 samples from the Aguardiente and the Capacho Formations. Palynology suggests an Albian-Early Cenomanian age for the sequence. The Aguardiente accumulated in transitional environments while the Capacho accumulated in shallow marine environments.
\end{abstract}

Keywords: Catatumbo basin Colombia, Cretaceous, Palynology, Capacho Formation, Aguardiente Formation.

How to cite: Rodriguez-Forero, Guillermo., De la parra- Bonilla, Felipe., Vargas, María.C., Bedoya, Omar,G. (2017). Palynology of the Aguardiente and Lower Capacho Formations, Catatumbo basin, Colombia. CT\&F - Ciencia, Tecnología y Futuro, 7(1), 31 - 42.

*To whom correspondence should be addressed 


\title{
RESUMEN
}

$\mathrm{L}$

a cuenca del Catatumbo se encuentra localizada en la parte nororiental de Colombia y es la contraparte de la cuenca de Maracaibo en Venezuela. Los principales reservorios se encuentran en la secuencia Cenozoica. Sin embargo, históricamente la secuencia Cretácica ha reportado buenos resultados en términos de producción de hidrocarburos. Este hecho ha renovado el interés en explorar y probar esta secuencia tanto para Hidrocarburos convencionales como para no convencionales. A este respecto, la formación Aguardiente es uno de los principales reservorios de la cuenca. Aunque ha sido perforado y estudiado en diferentes pozos, aspectos claves como su edad, ambiente de depósito y relación cronoestratigráfica con otras unidades aún no es claro. En este trabajo se presentan los resultados del análisis palinológico efectuado en 86 muestras de la Formación Aguardiente y la parte baja de la Formación Capacho. Dichos datos permitieron establecer un marco bioestratigráfico basado en palinomorfos y con el cual fue posible establecer una serie de eventos que sugieren una edad Albiano - Cenomaniano para el intervalo analizado. Adicionalmente se presentan evidencias palinológicas de un posible ambiente de depósito marino somero de estas unidades.

Palabras clave: Cuenca del Catatumbo Colombia, Cretácico, Palinología, Formación Capacho, Formación Aguardiente.

\section{RESUMO}

\begin{abstract}
$\Delta$
bacia do Catatumbo localiza-se na região nordeste da Colômbia e é a contraparte da bacia de Maracaibo, na Venezuela. Na sequência Cenozoica encontram-se os principais reservatórios. No entanto, historicamente a sequência Cretácica tem revelado bons resultados em termos de produção de hidrocarbonetos. Este fato tem renovado o interesse em explorar e testar esta sequência tanto para hidrocarbonetos convencionais, quanto para não convencionais. Neste contexto, a Formação Aguardiente é um dos principais reservatórios da bacia. Embora tenha sido perfurado e estudado em diversos poços, aspectos chaves como sua idade, ambiente de deposito e relação cronoestratigráfica com outras unidades ainda não está claro. No seguinte trabalho apresentam-se os resultados da análise palinológica praticada em 86 amostras da Formação Aguardiente e a região baixa da Formação Capacho. Esses dados permitiram o estabelecimento de um marco bioestratográfico baseado em palinomorfos e com o qual foi possível estabelecer uma série de eventos que sugerem uma idade Albiana-Cenomaniana para o intervalo analisado. Além do mais, apresentam-se evidencias palinológicas de um possível ambiente de depósito marino superficial destas unidades.
\end{abstract}

Palavras-chave: Bacia do Catatumbo Colombia, Cretácico, Palinologia, Formação Capacho, Formação Aguardiente. 


\section{INTRODUCTION}

\section{Geological Framework}

The sedimentary record of the Catatumbo Basin (Figure 1) starts at the end of the Lower Cretaceous (Aptian) with a shallow marine sequence (Tibú, Mercedes, Aguardiente, Cogollo and La Luna Formations). This sequence is followed by fine-grain and sandstone sequences deposited during the Late Cretaceous corresponding to the Colon and Mito Juan Formations (Figure 1). During the Triassic, Jurassic and Cretaceous, Colombia was affected by a rifting related to the separation of North and South America (Jaillard, Soler, Carlier \& Mourier, 1990). The sedimentary Cretaceous in the basin was deposited in this environment. The progressive oblique collision between the Caribbean plate and the Northern margin of South America during the end of the Cretaceous and the Early Cenozoic, generated a series of deformation events conditioning the evolution of the Northern Andes and its adjacent basins (Case, Duran, Lopez, \& Moore, 1971, Villamil \& Pindell, 1998, Montes, Hatcher, Restrepo-Pace, 2005).

Oil production in the Catatumbo basin began in 1920. Although the major reservoirs are found through the Cenozoic, the Cretaceous sequence has also reported good results. Major fields including Carbonera, Petrólea and Río de Oro have reported production from the Cretaceous.

In recent years, the exploratory activity of ECOPETROL in the Catatumbo basin has focused on both conventional and non-conventional (mainly gas shale) resources in areas with high structural complexity and deep naturally-fractured reservoirs. Exploratory campaigns often comprise the testing of multiple objectives and reservoirs from different ages. The Aguardiente Formation is one of the most important drilling objectives. Its type section is the Aguardiente Hill (Notestein et al., 1944), in Norte de Santander department in Colombia. This unit was initially described as the upper member of the Uribante Formation (Notestein, Hubman \& Bowler, 1944). Sutton (1946) defined it as a Formation (Julivert, 1968). The Aguardiente Formation comprises a sequence of predominantly glauconite sandstone with interbedded carbonaceous shale and calcareous levels. It has an average thickness of 148 meters. Based on ammonites, Aguardiente has been dated as Albian (Julivert, 1968). This unit overlies the Tibú-Mercedes Formation and underlies the Capacho Formation (Figure 1). The Capacho Formation is the unit that overlies the Aguardiente. Its type section is located in the Capacho Hill, in The Tachira State, Venezuela. Gonzalez (1951, in Julivert, 1968) measured a reference section in the Sardinata - Gramalote Road, in the Riecito River. According to Sutton (1946, in Jullivert, 1968) and Rod \& Maynic (1954, in Jullivert, 1968)) the Capacho Formation corresponds to the stratigraphic interval located between the Aguardiente and the La Luna Formations. This interval was also called the Cogollo Group by Notestein et al. (1944) in the Barco Concession, based in the recognition of three Formations: the Lower, Middle and Upper Cogollo. This proposal created confusion in the use of the two terms. For that reason, Maync (in Julivert, 1968 and Richards, 1967 in Julivert 1968) proposed to use only the term Capacho Formation, even in the Barco Concession. According to Gonzalez (1951, in Julivert, 1968) in the Riecito river section, the three members of the Capacho (Lower, Middle and Upper Cogollo of Notestein et al., 1944) are recognized. The Lower Member, studied in this paper, corresponds to a $138 \mathrm{~m}$. series of dark gray to black, hard, partly calcareous and micaceous shales with interbedded limestone in the upper $60 \mathrm{~m}$. These limes are dark gray, argillaceous, wavy and flaggy-to slabby-bedded (Richards, 1957 in Julivert, 1968).

Here we present the palynological results from five wells that drilled the Aguardiente Formation and the Lower Capacho (Table 1). A biostratigraphic framework for this unit was established. Biostratigraphic events including First Appearance Datum (FAD), Last Appearance Datum (LAD) and ACME's (Abundances) were evaluated by the Graphic Correlation method. The palynological data allowed us to make inferences about the possible deposition environment of the unit, as well as its age.

\section{EXPERIMENTAL DEVELOPMENT}

We analyzed the palynological information from four wells drilled in the Catatumbo basin and one outcrop section (Figure 2, Table 1). A total of eighty-six (86) well- ditch cutting samples were analyzed (Table 1). 

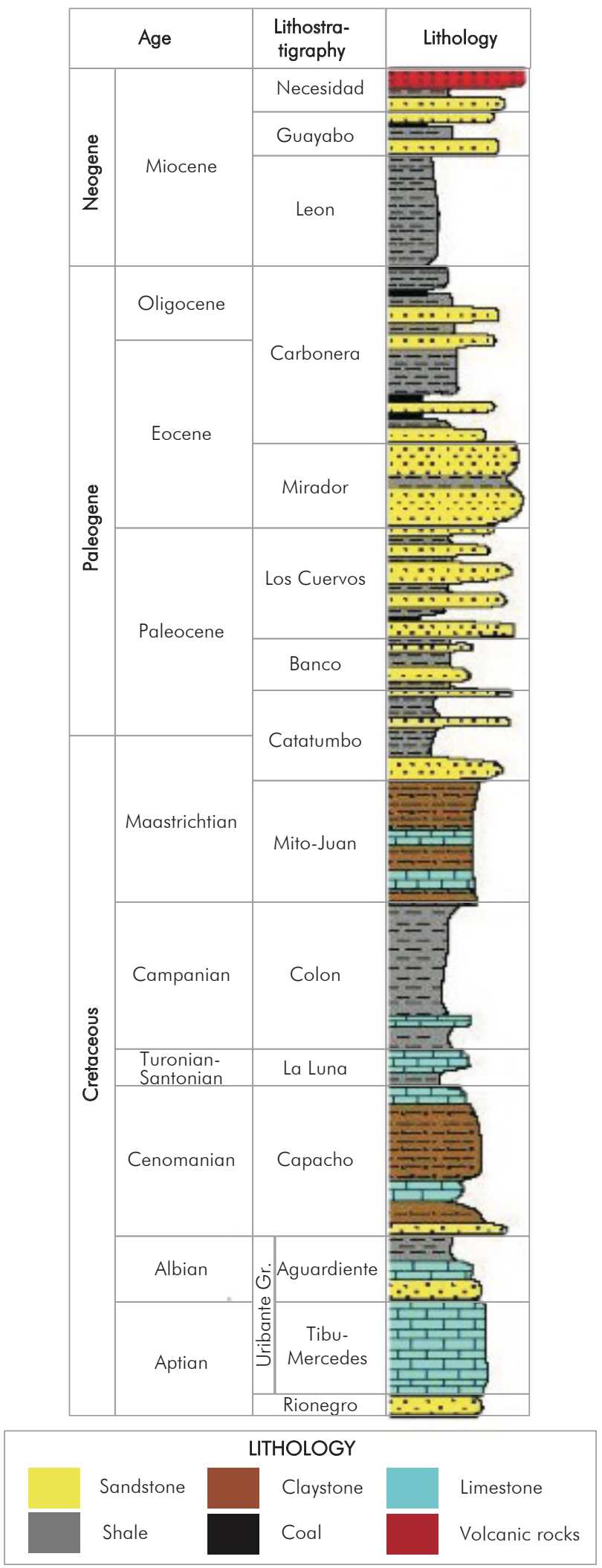

Figure 1. General Cretaceous-Neogene stratigraphic column of the Catatumbo Basin (modified from Notestein et al., 1944, Blanco et al., 2008).
Table 1. Analyzed wells and outcrop section and numbers of samples per section.

\begin{tabular}{|cccc|}
\hline Well & Latitude & Longitude & $\begin{array}{c}\text { \# Analyzed } \\
\text { samples }\end{array}$ \\
\hline Alamos-1 & 8.9482 & -73.0189 & 47 \\
\hline Tibu-408 & 8.699306 & -72.739053 & 16 \\
\hline Carbonera-5k & 8.391 & -72.515 & 53 \\
\hline Oripaya-1 ST1 & 8.0772 & -72.4293 & 31 \\
\hline Sardinata section & 8.043 & -72.8037 & 28 \\
\hline
\end{tabular}

Samples were prepared in the Instituto Colombiano del Petróleo (ICP as per its acronym in Spanish) following the standard procedure of digesting the sediments in $\mathrm{HCl}$ and $\mathrm{HF}$ and then oxidizing (Traverse 2007). The identification of the palynomorphs was performed by comparison with published literature and with the palynological reference collection of fossil palynomorphs hosted at the ICP.

We produced a biostratigraphic framework using Graphic Correlation (Shaw 1964: Edwards 984), using GraphCor ${ }^{\circledR}$ (Hood 1988). A bivariate (XY) plot (Figure 3) is use to compare the stratigraphic position of biostratigraphic events (First Appearance Datum or FAD, Last Appearance Datum of LAD and high frequencies or ACMES); a line of correlation is drawn to establish the temporal equivalence between sections. The line of correlation can be traced either manually or by using statistic methods, like genetic algorithms (Edwards, 1989, Zhang, 2000). This procedure is applied to all sections (in this case 5) to produce a composite section and to establish the stratigraphic range of all species. The new species range is expressed in terms of composite units (cu) corresponding to the measured units of the Reference Section. Because all the samples used in this study are ditch cuttings, FAD's were not used to avoid the effect introduced by caving. The outcrop section (Sardinata) has low sampling due to a great amount of covered interval, and low recovery due to high thermal alteration. The Alamos-1 well was used as the Reference Section because is the most complete in terms of sampling and palynological recovery. Two rounds of correlation were performed, reaching the stability of every taxon range. Because of the biostratigraphic, events not occurring exactly at the same stratigraphic level across the sections thus, their extrapolation from 


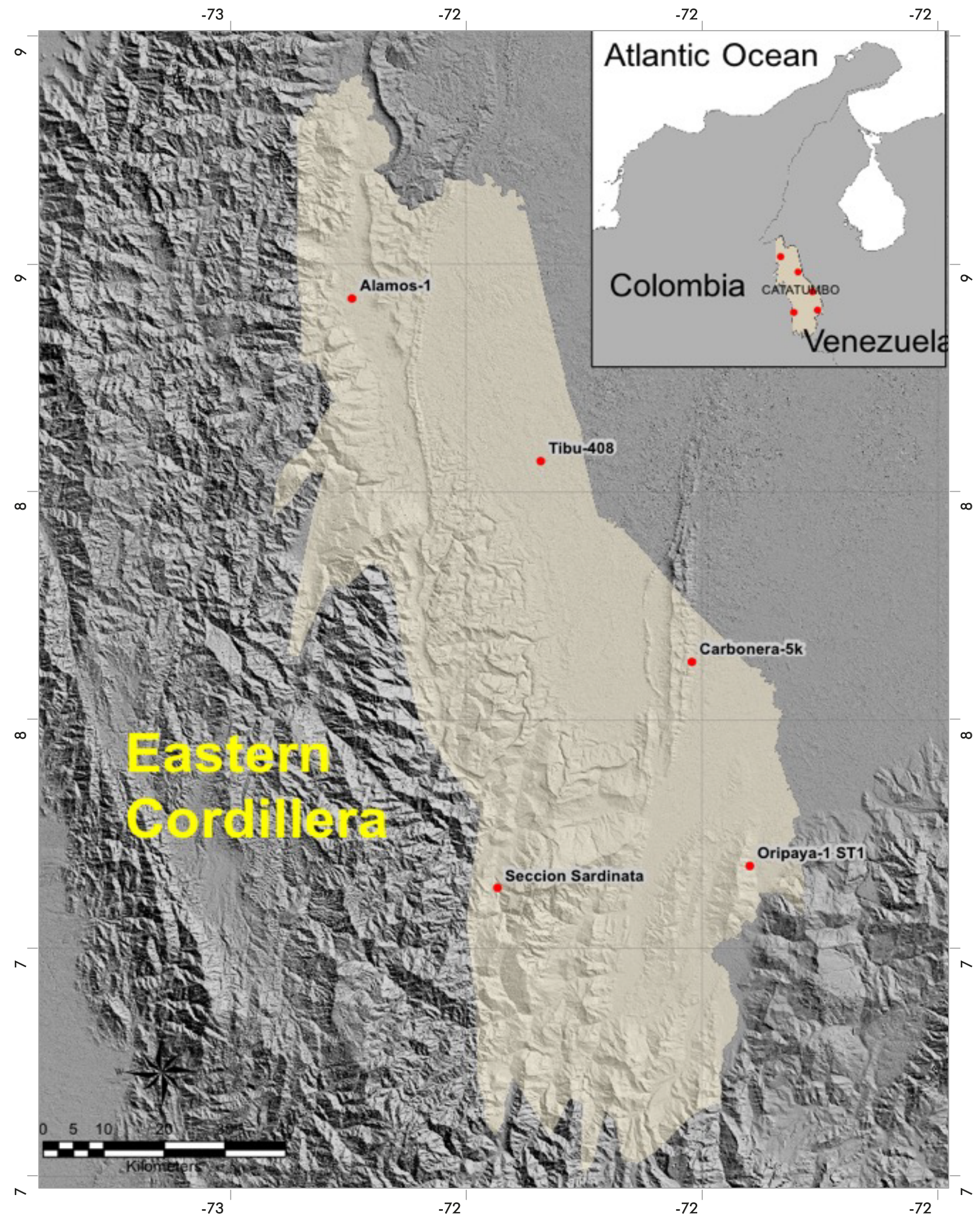

Figure 2. Location of the analyzed sections of this study. 
a single section to the composite section); a spreading parameter (Jaramillo et al., 2011, Jaramillo et al., 2005) was calculated in order to evaluate the confidence of the position of each event (in this case LAD and LAD of an ACME) in the Reference Section (Table 2). This is also a way to identify whether each event could be useful as a correlation event. The main idea for this study was to determine how dispersed could the position of each event be in the Reference Section. For this reason, the Spreading parameter was calculated by subtracting the position of the oldest extrapolated LAD and the youngest extrapolated LAD.

The Thermal Alteration Index (TAI, Staplin, 1969, 1977 in Traverse, 2007) was calculated to assess the thermal maturation of the organic matter.

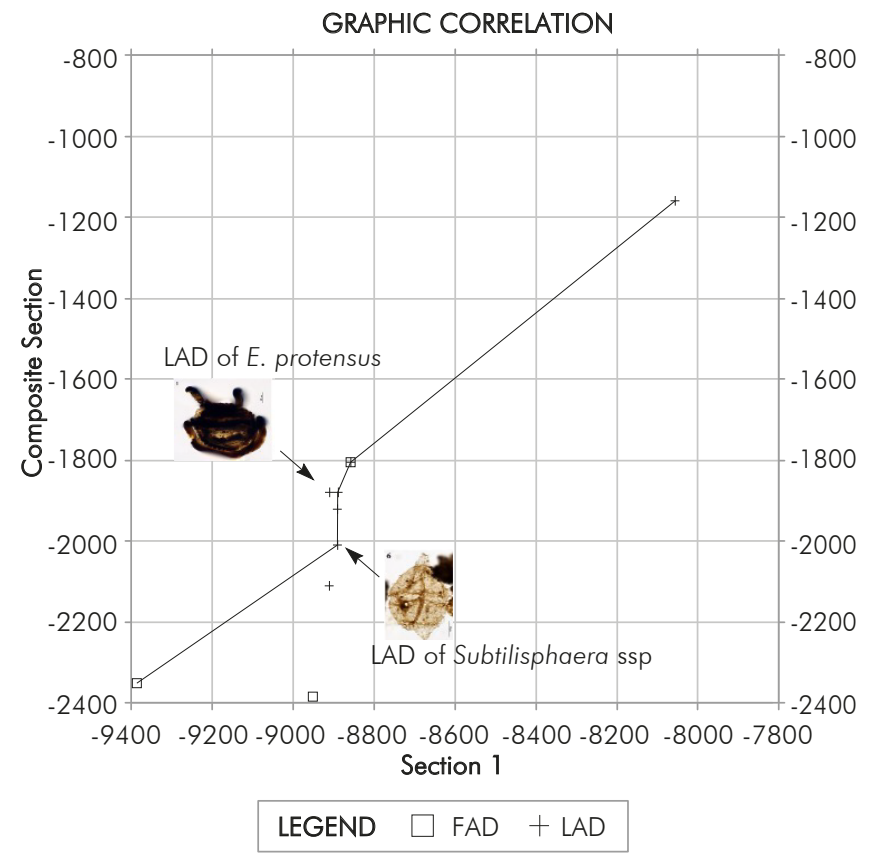

Figure 3. Example of Graphic correlation

\section{RESULTS}

The recovery of continental organic matter is good, and the palynoflora recovery is moderated. TAI ranges from $2+$ in the North to 3 at the South. Common palynomorphs include Classopollis, sp., Classopollis classoides, Afropollis spp. Callialasporites dampieri, Psilatriletes sp and Elaterosporites protensus. In two wells, (Alamos-1 and Tibu-408, see annex 1) two events with high abundance (ACME) of the dinoflagellate cyst Subtilisphaera spp. were observed in the middle part of the Aguardiente Formation.

The preliminary sequence of events is composed by seven (7) palynological events. Five palynological events were identified in the Aguardiente Formation. Most of these events were found only in one or two wells, and very few were found across all the studied sites. From bottom to top, the events are: The LAD of high frequencies of Subtilisphaera (Subtilisphaera ACME 2), LAD of high frequencies of the Classopollis pollen genus (Classopollis ACME), the LAD of Elaterosporites protensus, again high frequencies of Subtilisphaera (Subtilisphaera ACME 1), and the LAD of Calialasporites dampieri and the genus Classopollis and Two events in the Capacho Formation, described by Psilatriletes $<25 \mathrm{mic}$. ACME (LAD of the ACME) and Dinoflagellates ACME (LAD of the ACME) (Table 2, Figure 4). In all the studied wells a change in the organic matter composition is observed in the Aguardiente - Capacho's s transition. Aguardiente is dominated by the continental organic matter while, amorphous organic matter dominates the lower part of the Capacho Formation.

Table 2. Sequence of the observed palynological events of the Capacho - Aguardiente Formation and number of wells were the events are observed.

\begin{tabular}{|cccc|}
\hline EVENT & TOP (cu) & \# wells & $\begin{array}{c}\text { Spreading } \\
\text { parameter } \\
\text { (cu) }\end{array}$ \\
Capacho Fm. Top & 1160 & 5 & ---- \\
\hline Psilatriletes <25mic. ACME & 1210 & 4 & 341 \\
\hline Dinoflagellates ACME. & 1510 & 1 & Uncertain \\
\hline Aguardiente Fm. Top & 1804 & 5 & ---- \\
\hline Afropolis jardinous LAD & 1840 & 2 & 333 \\
\hline Callialasporites dampieri LAD & 1880 & 3 & 20 \\
\hline Classopollis classoides LAD & 1880 & 4 & 339 \\
\hline Subtilisphaera spp. ACME 1 & 1920 & 2 & 80 \\
\hline Elaterosporites protensus LAD & 1950 & 1 & Uncertain \\
\hline Classopollis spp. ACME & 2010 & 3 & 199 \\
\hline Subtilisphaera spp. ACME 2 & 2024 & 2 & 235 \\
\hline
\end{tabular}



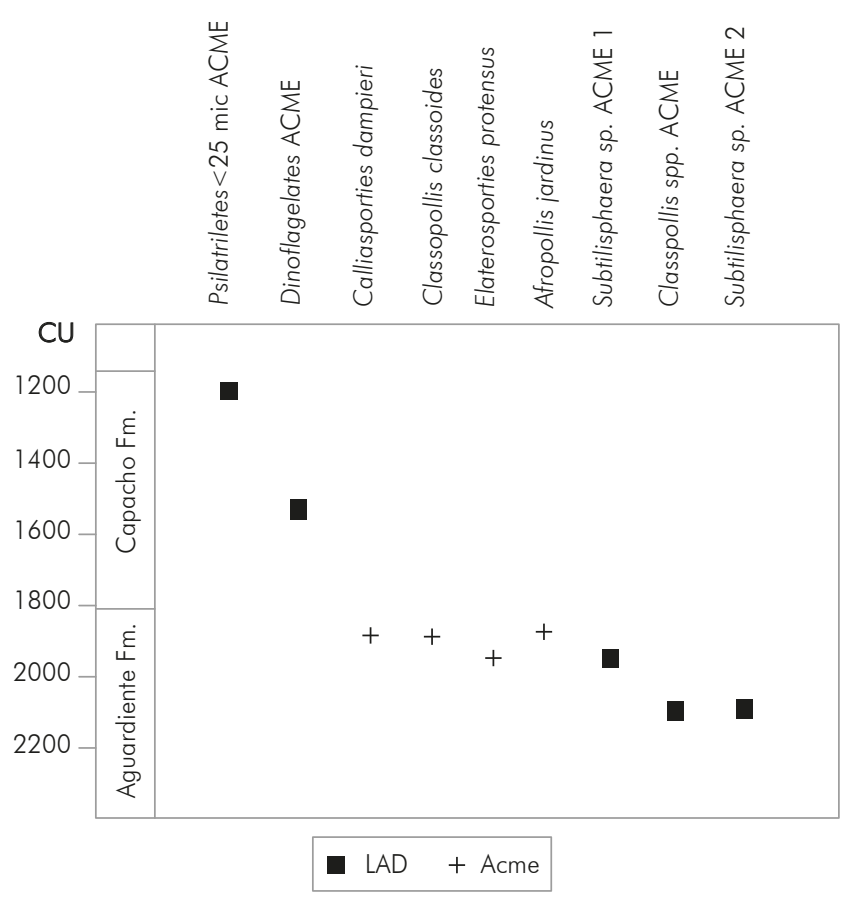

Figure 4. Sequence of identified events and its stratigraphic position in the composite section.

\section{RESULTS ANALYISIS}

High thermal alteration of the Aguardiente Formation, indicated by our TAI analysis, strongly affects the preservation and recovery of the organic matter and palynomorphs. We found the thermal alteration to be higher in the South (Oripaya -1, TAI 3) than in the North (Alamos -1,TAI 2+). Mondragón et al. (2002, internal report) based on vitrinite reflactance (Ro) also concludes that the thermal maturity of the Uribante Group (Tibu, Mercedes and Aguardiente Formations) is very high, ranging from mature to the North to over mature to the South.

Although most of the events keep the same stratigraphic order in all wells, many of them have high spreading parameter (Table 2.) Only Callaliasporites dampieri records a variation of 20 composite units, but that is not seen in all wells. Afropollis jardinus, and Elaterosporites protensus LADs, good chronostratigraphic markers are very uncertain. This could be the reflection of the preservation due to Thermal alteration and facies controls. Nevertheless, LADs of Callialasporites dampieri and Afropollis jardinus and the occurrence of Elaterosporites protesus were found in the Aguardiente Formation, and could be useful for dating purposes. Caliallasporites dampieri has been reported from the Jurassic in Canada, India and Europe (Norris, 1970, Srivastava, 1966, Srivastava, 1987) up to the Albian in Egypt and Canada (Fensome \& Norris, 1982, Ibrahim, 1996). It also has been reported in Tanzania and South America up to the Early Cenomanian (Srivastava, 1987, Brenner, 1976, Herngreen, 1975, Muller, Di Giacomo \& Van Erve, 1987, Jaramillo \& Rueda, 2004, De la Parra et al., 2011). Elaterosporites protensus has been reported from the Late Albian to Early Cenomanian in South America and Africa (Jardine, 1967, Herngreen, 1975, Brenner, 1976, Muller et al., 1987, Batten, 1996, Jaramillo \& Rueda, 2004, De la Parra et al., 2011). Afropollis jardinus has been recorded in Africa and South America from the Middle Albian (Doyle, Jardine \& Doerenkamp, 1982; Ibrahim, Aboul Ela, \& Kholeif, et al., 2001) up to the Early Cenomanian (El Beialy, Head \& El Atfy., 2010). Herngreen \& Dueñas (1995) found these two species associated with Classopollis spp., Cicatricosisporites venustus, and Afropollis Jardinus in the Upper part of the Une Formation of the Llanos Basin and were related to the Albian-Cenomanian South Anerican-African Province (ASA, Herngreen, 1975, 1981, Herngreen and Cholonova, 1981, Herngreen et al., 1996). This association was also found in the Aguardiente. Based on this information, these events could suggest a Middle Albian - Early Cenomanian age for the Aguardiente Formation. The events recognized within the Lower Capachos do not allow to make any age interpretation and are very uncertain. In addition the palynological events could be facies-controlled and/or preservation controlled. However, the Lower part of the Capachos would be Late Albian - Early Cenomanian (Early Canomanian?) as well, assuming that the association of the ASA Province could be extended to this part of the Formation. These interpretations need to be complemented with more studies of more sections along the basin to calibrate the interpretations and to compare the order of the observed events.

The depositional environment of the Aguardiente Formation has been interpreted as transitional, whereas the Capacho Formation was deposited in a shallow marine environment (Olaya \& Linares, 1998). Our palynofacies observations suggest a decrease in the continental supply of organic matter during the accumulation of the lower segment of the Capacho Formation. In addition, within the Aguardiente, many LADs of continental palynomorphs (Classopollis, sp., Cicatricosisporites venustus, Classopollis classoides, Afropollis spp. 
Callialasporites dampieri and Elaterosporites protensus) are observed (Table 2). In Alamos -1 there is a dinocyst ACME in the lower part of the Capacho. This ACME is represented by high frequencies of Palaeohystricophora infusorioides, Subtilisphaera, Diphyes and Coronifera. Harris \& Tocher (2003) suggest that these assemblies are related to high productivity. These evidences of environmental changes between the Aguardiente and the Lower Capacho could suggest faces control of the palynological events, recognized in this interval.

In Alamos -1 and Tibu - 408 at the Northern part of the basin, two dinocysts ACME events (Subtilisphaera ACME 1 and 2) are recognized. These events suggest some marine influence within the Aguardiente. Toward the South, marine influence is not recognized, probably because the depositional environments were more continental.

\section{CONCLUSIONS}

- We suggest a probable Albian - Cenomanian age for the Aguardiente - Lower part of the Capacho Formations as a palynological approach.

- Thermal maturity of the Cretaceous Sequence in the Catatumbo Basin is high, being higher toward the South.

- Palynoflora suggests transitional depositional environments for the Aguardiente Formation, while reflecting a deepening in the Lower part of the Capacho Formation.

- Palynological events could be facies controlled, regarding that many LADS were found within Aguardiente and very few within Capacho.

- It is highly recommended to conduct more palynological studies in the Basin, as well as Chronology studies in order to refine age interpretations.

\section{ACKNOWLEDGEMENTS}

Special thanks to ECOPETROL-ICP for the permission to publish the data and to Carlos Jaramillo and two anonymous reviewers for their comments and suggestions that improved the manuscript.

\section{REFERENCES}

Batten,D.J. (1996). Upper Jurassic and Cretaceous miospores. Palynology: American Association of Stratigraphic Palynologists. (J.Jansonius and D.C.McGregor, Editors) Vol. 2: 807- 830

Brenner, G. J. (1976). Middle Cretaceous Floral Provinces and Early Migrations Of Angiosperms. Origin and Early Evolution Of Angiosperms. Cb Beck, Ed.

Blanco, V., García, D., Giraldo, B., Blanco, Y., Gallo, M. (2008). Ocurrencia de cocinas de generación activas Terciarias y Cretácicas y aproximación a la temporalidad de la carga de hidrocarburos en la cuenca del Catatumbo. ECOPETROLICP, internal report.

Case, J.E., Duran, S.L.G., Lopez, R.A. and Moore, W.R., 1971. Tectonic investigations in western Colombia and eastern Panama. Geological Society of America Bulletin, Vol. 82(10): 2685-2712.

De La Parra, F., Jaramillo, C., Rueda, M., Vargas, M., Santos, C., Mantilla, F., Montes, C., Romero, M., Silva, C., Paez, M., Moreno, C., Garzon, S., Etayo-Serna, F., Cardona, A., Salazar, E., Zapata, V., Quiroz, L., Rojas, A., Ortiz, J., And Moreno, C. (2011). Proyecto Cronología de las Secuencias Bioestratigráficas del Cretácico del Piedemonte Llanero: Ecopetrol-ICP y Smithsonian Tropical Research Institute.

Doyle,J.A. Jardine, S., Doerenkamp, A. (1982) Afropollis, a new genus of early angiosperm pollen, with notes on the Cretaceous palynostratigraphy and paleoenvironments of Northern Gondwana. Bulletin des Centres de Recherches Exploration-Production Elf-Aquitaine Vol. 6 (1): 39- 117

Edwards, L.E. (1984). Insights on why graphic correlation (Shaw's method) works. J. of Geology, 92:583-597.

Edwards, L.E. (1989). Supplemented graphic correlation: a powerful tool for paleontologists and nonpaleontologists. Palaios, 4: 127-143.

Harris, A.J., Tocher, B.A. (2003). Palaeoenvironmental analysis of Late Cretaceous dinoflagellate cyst assemblages using high-resolution sample's correlation from the Western Interior Basin, USA. Marine Micropaleontology 48: 127-148. 
El Beialy, S.Y., Head, M., El Atfy, H.S. (2010). Palynology of the Mid-Cretaceous Malha and Galala Formations, Gebel El Minshera, North Sinai, Egypt. Palaios Vol. 25: 517-526.

Fensome,R.A., Norris, G. (1982) Palynostratigraphic comparison of Cretaceous of the Moose River Basin, Ontario, with marginal marine assemblages from the Scotian Shelf and Alberta. Ontario Geological Survey, Miscellaneous Paper Vol. 103: 37- 42.

Herngreen,G.F.W. (1975). Palynology of Middle and Upper Cretaceous strata in Brazil. Mededelingen Rijks Geologische Dienst, Nieuwe Serie Vol. 26 (3): 39- 90 .

Herngreen, G.F.W. and Chlonova, A.F., (1981). Cretaceous microfloral provinces. Pollen et Spores, Vol. 23(3-4): 441-455.

Herngreen, G. F. W., \& Jimenez, H. D. (1990). Dating of The Cretaceous Une Formation, Colombia And The Relationship With The Albian-Cenomanian African-South American Microfloral Province. Review of Palaeobotany And Palynology, 66(3-4): 345-359.

Herngreen, G. F. W., Kedves, L. V. Rovnina, \& Smirnova Sb (1996). Cretaceous Palynofloral Provinces: A Review. Palynology: Principles And Applications-American Association Of Stratigraphic Palynologists Foundation, Vol. 3(1), 157-1.

Hood, K.C. (1998). GraphCor Interactive Correlation Software. Houston:Hood, K.C.

Ibrahim, M.I.A., (1996). Aptian-Turonian of the Ghazalat-1 Well (GTX-1), Qattara Depression, Egypt. Review Palaeobotany Palynology Vol. 94, 137-168.

Ibrahim, M.I.A., Aboul Ela, N.M., And Kholeif, S.E., (2001) Palynostratigraphy of Jurassic to Lower Cretaceous sequences from the Eastern Desert of Egypt: Journal of African Earth Sciences, Vol. 32: 269-297.

Jardine,S. (1967) Spores with Projections similar to Elaters from the Middle Cretaceous of West Africa. Review of Palaeobotany and Palynology Vol. 1: 235- 258.

Jaramillo, C., Rueda, M. (2004). Impact of biostratigraphy on Oil Exploration. III Convención técnica ACGGP. La inversión en el conocimiento geológico. ACGGP, Bogotá.
Jaramillo C., Muñoz F., Cogollo M., Parra F. (2005). Quantitative biostratigraphy for the Paleocene of the Llanos Foothills, Colombia: Improving palynological resolution for oil exploration. In: Powell A.J., Riding J., editors. Recent developments in applied biostratigraphy. Bath (UK): Geological Society Publishing House (The Micropaleontological Society Special Publication TMS001): 145-159.

Jaramillo, C., Rueda, M., Torres, V. (2011). A Palynological Zonation for the Cenozoic of the Llanos and Llanos Foothills. Palynology, Vol. 35 (1), 46-84.

Jaillard, E., Soler, P., Carlier, G., Mourier, T. (1990). Geodynamic evolution of the Northern and Central Andes during Early to Middle Mesozoic times: a Thetyan model. Journal of the Geological Society of London Vol. 147:10091022.

Julivert, M. (1968). Léxico Estratigráfico Internacional. Union Internationale des Sciencies Géologiques. Amérique Latine. Volumen 5 (4a). Colombia. 150 - 153, 177 - 185.\}

Montes, C., Hatcher Jr., R.D., Restrepo-Pace, P. (2005). Tectonic reconstruction of the Northern Andean Blocks: oblique convergence and rotations derived from the kinematics of the Piedras-Girardot Area, Colombia, Tectonophysics Vol 399 (1-4):221-250.

Mondragón, J.C., Alfonso, C.A., Córdoba, F., García, D., Gonçalvez, F., Mora, C., Guevara, S., Rubio, R., Muñoz, F., Hernández, R., Medina, A., Ramírez, R. (2002). Proyecto de evaluación regional de la cuenca del Catatumbo. Informe interno, Ecopetrol.

Muller, J., Di Giacomo, E., Van Erve, A., (1987) A palynologic zonation for the Cretaceous, Tertiary and Quaternary of Northern South America: American Association of Stratigraphic Palynologists Contribution Series, Vol. 19: $7-76$

Norris,G. (1970) Palynology of the Jurassic-Cretaceous boundary in Southern England. Geoscience and Man Vol 1: $57-65$.

Notestein, F, B., Hubman, C, W. \& Bowler, J. W. (1944). Geology of the Barco Concession, Republic of Colombia, South America. Bulletin of the Geological society of America. 55: 1165-1216. 
Olaya I., Linares R. (1998). Patronamiento bioestratigráfico y correlación subsuelo-superficie del área sur de la Cuenca del Catatumbo. ECOPETROL-ICP-AEX.

Regali,M.S.P., Uesugui,N., Santos,A.S. (1974) Palynology of Mesozoic-Cenozoic Sediments of Brazil (I and II). (Vol. 17(3), Pages: 177-191). (Vol.17(4), Pages: 263-301.) Palinologia dos sedimentos Meso-Cenozoicos do Brasil (I And II). Boletim Técnico da Petrobras Vol. 17 (3): 177- 301.

Richards, H. G., (1968) Cretaceous Section in Barco area of northeastern Colombia, Bulletin of the American Association of Petroleum Geologists Vol. 52 (12): 324 - 336

Rod, E. And Maync, W., (1954). Revision of Lower Cretaceous stratigraphy of Venezuela. Bulletin of the American Association of Petroleum Geologists Vol. 38 (2):193-283.

Rueda, M. (2008). Reporte Palinologico Pozo Tempranillo-1 (Intervalo 5910-10540). Informe Interno 09-08, EcopetrolICP.

Srivastava,S.K. (1987) Jurassic spore-pollen assemblages from Normandy, (France and Germany). Geobios Vol. 20: 5- 79.

Srivastava,S.K. (1966) Jurassic microflora from Rajasthan, India. Micropaleontology Vol. 12 (1): 87- 103.

Shaw, A.B. (1964). Time in Stratigraphy. New York: McGrawHill. 365 p.

Sutton, F. A. (1946). Geology of Maracaibo basin, Venezuela. Bulletin of the American Association of Petroleum Geologists., 30: 1621-1741.

Staplin, F. L., (1969) Sedimentary organic matter, organic metamorphism, and oil and gas occurrences, Bulletin of Canadian Petroleum Geology Vol. 17:47-66.

Staplin, F. L., (1977) Interpretation of thermal history from color of particulate organic matter-a review, Palynology Vol. 1:9-18.

Traverse, A. (2007). Paleopalynology. New York Academic press, $600 \mathrm{pp}$.

Villamil, T. and Pindell, J.L. (1998). Mesozoic paleogeographic evolution of northern South America: foundations for sequence stratigraphic studies in passive margin strata deposited during non-glacial times. In: J.L. Pindell and C.L. Drake (Editors), Paleogeographic evolution and non-glacial eustasy, northern South America. Special Publication. SEPM, Tulsa:. 283-318.

Zhang, T. (2000). Artificial Intelligence models for Quantitative Biostratigraphy. PhD Thesis. University of Illinois.

\section{AUTHORS}

\section{Guillermo Rodríguez Forero}

Affiliation: Ecopetrol S.A - Instituto Colombiano del Petróleo,

Piedecuesta, Colombia.

e-mail: guillermo.rodriguezf@ecopetrol.com.co

\section{Felipe de la Parra-Bonilla}

Affiliation: Ecopetrol S.A - Instituto Colombiano del Petróleo, Piedecuesta, Colombia.

e-mail: felipe.delaparra@ecopetrol.com.co

\section{María Carolina Vargas Fúquene}

Affiliation: Ecopetrol S.A - Instituto Colombiano del Petróleo,

Piedecuesta, Colombia.

e-mail: maria.vargas@ecopetrol.com.co

\section{Omar Giovanni Bedoya Martínez}

Affiliation: Ecopetrol S.A - Instituto Colombiano del Petróleo,

Piedecuesta, Colombia.

e-mail: omar.bedoya@ecopetrol.com.co 


\section{ANNEX 1}

Figure A. Plate 1
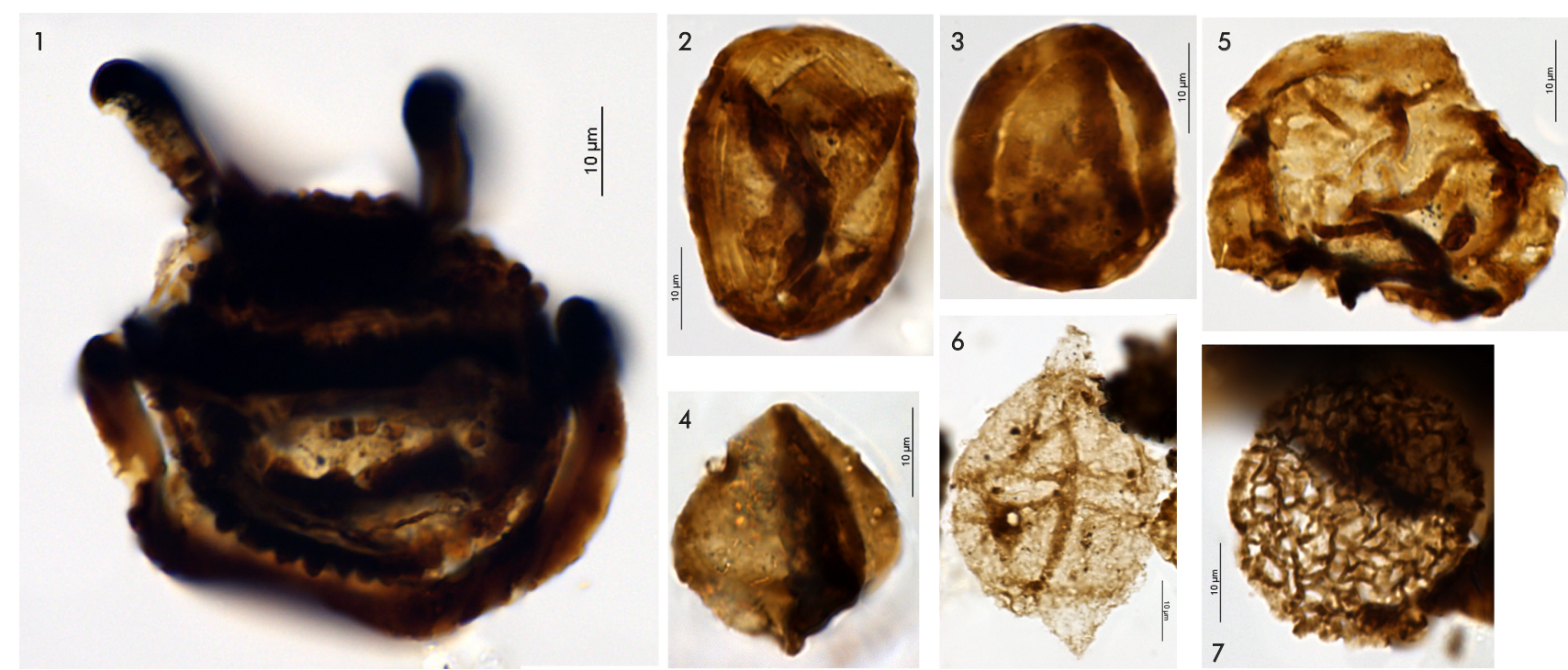

1. Elaterosporites protensus (Stover 1963) Jardine 1967

2. Classopollis classoides Pocock and Jansonius 1961

(Alamos-1 1959' EF:W54-4);

(Alamos-1 1920' EF:O19-3);

3. Classopollis sp.

4. Psilatriletes $<25 u m$

5. Callialasporites dampieri (Balme 1957) Dev 1961.

6. Subtilisphaera spp. Letin and Williams 1976.

7. Afropollis jardinus Doyle, Jardine and Doerekamp 1982

(Alamos-1 2350' EF:D8);

(Alamos-1 1300' EF:acme);

(Alamos-1 2350' EF:R55);

(Alamos-1 1630' EF:W12-4 acme);

(Alamos-1 2010' EF:N11(1); 
